\title{
Biodigestores en Unidades Productivas Agropecuarias (UPAs): un proceso para combatir la RAM, producir energía renovable y fertilizante de alta calidad. Proyecto piloto Inventagri
}

\author{
Molina-Cuasapaz, Gabriel ${ }^{1}$; Leoro Garzón, Paula²; Romero Borja, Elvis ${ }^{3}$; Cevallos, Fabian ${ }^{4}$ \\ ${ }^{1}$ Universidad Técnica de Cotopaxi, Facultad de Ciencias Agropecuarias y Recursos Naturales, Carrera de Medicina \\ Veterinaria, Latacunga, Ecuador. \\ 2 Inmunolab, Quito, Ecuador. \\ ${ }^{3}$ Life Sciences Intiative. Research Unit, Quito, Ecuador \\ ${ }^{4}$ Inventagri, Quito, Ecuador. \\ e-mail: edie.molina7278@utc.edu.ec
}

Palabras clave: Biol, biodigestor, Escherichia coli, energía renovable, resistencia bacteriana.

INTRODUCCIÓN: En la actualidad las alternativas antibióticas se han visto reducidas por el dramático incremento de la resistencia bacteriana a los antimicrobianos (RAM), en gran medida debido a su uso inadecuado en producción animal "actualmente se emplea un mayor volumen de antibióticos para animales sanos que para tratar personas enfermas". [1] Las Unidades Productivas Agropecuarias (UPAs), descargan grandes cantidades de materia fecal cargada de bacterias multirresistentes en los cuerpos de agua [2], mediante los cuales se diseminan en todo el ecosistema. Las iniciativas de producción de biofertilizante y biogás a partir de estos desechos fecales se han visto renovadas debido al desarrollo de nuevos sistemas de biodigestión. [3] Sin embargo, pocos estudios han evaluado su potencial para reducir la diseminación de la RAM.

OBJETIVO: Evaluar el efecto de la biodigestión en el conteo de E. coli resistente a cefalosporinas de tercera generación (R-C3G) en los desechos fecales de una UPA.

MATERIALES Y MÉTODOS: Se tomaron muestras por triplicado en la entrada del biodigestor (Homebiogas 2.0) y su salida. En las muestras se cuantificó E. coli (R-C3G) por filtración en placas de TBX $+3 \mu \mathrm{g} / \mathrm{ml}$ de cefotaxima. Los aislados se caracterizaron mediante MALDI-TOF, Kirby-Bauer,
PCR de los genes bla ${ }_{\text {Стх-м }}$ de los grupos 1, 2, 8 y 9, bla $_{\text {KPC }}$ y mcr-1 y la clonalidad de los aislados se estableció por BOX-PCR.

RESULTADOS: Se determinó una carga promedio de 1120 UFC E. coli R-C3G/mL en la entrada del biodigestor. Mientras que al finalizar el proceso el conteo cayó hasta límites no cuantificables por la técnica de filtración. Todos los aislados mostraron patrones de multirresistencia y fueron positivos para genes bla CTX-м $_{\text {( }}(8 / 10$, grupo 1 y $2 / 10$, grupo 9). El análisis de BOX-PCR indicó alta heterogeneidad entre los aislados.

CONCLUSIONES: Los datos sugieren que durante el proceso de fermentación dentro del biodigestor la gran mayoría de E. coli R-C3G son eliminadas y plantean su posible uso como una medida para limitar la diseminación de la RAM, que adicionalmente genera fertilizante y biogás sustentablemente en un solo proceso. Sin embargo, se requiere establecer el resistoma del biol previo a sugerir su uso para la contención de la RAM.

\section{REFERENCIAS:}

[1] J. O’Neil. Antimicrobial Resistance: Tackling a crisis for the health and wealth of nations", Rev. Antimicrob. Resist. 2014; 20: 1-16.

[2] Barba P, Ortega-Paredes D, Molina-Cuasapaz G, Zurita J. Occurrence of extended-spectrum 
beta-lactamase producing Escherichia coli in a dairy farm from Quito, Ecuador". [Internet]. 2017. Disponible en: DOI: 10.13140/ RG.2.2.21553.33121.

[3] Alexander S, Harris P, McCabe B K. Biogas in the suburbs: An untapped source of clean energy? J. Clean. Prod. 2019; 215: 1025-1035. 